\author{
Leila Almazova
}

\title{
Teaching Religion to Children in Contemporary Tatarstan: The Case of Islam
}

DOI: https://doi.org/10.22394/2311-3448-2018-5-2-44-62

Leila Almazova - Department of Oriental, African and Islamic Studies, Institute of International Relations, History and Oriental Studies, Kazan (Volga Region) Federal University (Russia). leila_almazova $@$ mail.ru

This article is devoted to the problem of children's instruction on Islam in the Republic of Tatarstan. Research is based on fieldwork in several rural districts and six cities carried out in June and July 2017, as well as on the analysis of curricula, textbooks, and publications on religious educational reforms. The study shows that the main factor in how religion is taught in public schools is the multiethnic and multireligious composition of the population (54 and 44 percent of Tatar and Russian populations respectively). Of the six available modules for the study of religion and ethics, only two are taught in Tatarstan - Foundations of World Religious Cultures and Foundations of Secular Ethics. The remaining four - Orthodox, Islamic, Judaic and Buddhist Cultures although widely taught in other Russian regions - are not utilized in the state schools of Tatarstan. This lack of religious instruction in public schools determines the intensity of children's intrareligious education. The case of Islam shows the diversity of forms of children's religious education: religion is taught in Muslim kindergartens, in special courses that operate near mosques, in summer camps, discussions and meetings with imams and Islamic clergy at schools, regular courses of Islamic ethics taught by imams at schools, and at Uthmaniya, the private general-education school founded in Kazan by the Tatarstan Muslim Religious Board. The case of Tatarstan, in which state and religious institutions have divided children's religious education into spheres of influence, is an interesting example of building relations between religion and the state in post-Soviet, post-secular societies.

Keywords: religious education, religion in secular school, Foundations of Religious Cultures and Secular Ethics, Islam, Muslim education for kids. 


\section{Introduction}

HE system of education in the Russian Federation is now in a state of transition and reform. New programs and standards are being introduced, documentation is being upgraded. All of this causes teachers, parents and children great concern. They complain about lack of stability, the drastic nature of the reforms, complicated programs and difficulties in passing the Standardized State Examination (Edinyi gosudarstvennyi ekzamen or EGE). Emile Durkheim wrote that public education has a social nature, and it cannot but react to social changes (Durkheim 1996, 49). In post-Soviet realities this applies to the multiple changes that have occurred during the last two to three decades.

For seventy years, the Soviet state clearly defined the goals of the educational system: "The main goal [is] . . . to make the school a true tool of communist upbringing and enlightenment, a conductor of the ideological, organizational, educational influence of the proletariat on the semi-proletarian and non-proletarian strata of the working masses" (Prokof'ev 1967).

The current Education Law of the Russian Federation, in turn, prioritizes certain aspects, proposing as its main principles: "the humanistic nature of education, the priority of human life and health, the rights and freedoms of the individual, the free development of the individual, the education of mutual respect, diligence, patriotism, responsibility, legal culture, careful attitude to nature and the environment, management of natural resources," as well as "an individual learning principle ... . Now the main task of the teacher is to identify and develop the specific abilities of each student" ("Zakon" 2017).

As the above citations show, in the Soviet era children were convinced that the USSR was building a bright future through communism, the main distinguishing feature of which would be the lack of money and satisfaction of people's needs. The modern concept of education does not provide as clearly articulated a picture, offering instead only rather abstract concepts. Apparently, it is precisely this absence of clarity that generates an intensified search for a certain system of values and goals shared by the majority that could be reflected in the educational system.

Religion offers modern society clearly articulated and historically tested positions. Survey data for 2012, with a sample of 3,000 respondents, indicated that 78 percent of Russians consider themselves believers, 13 percent vacillate, and only 6 percent are non-believers (Sinelina 2013). According to the latest sociological polls (June 
2017) of the Levada Center, the number of religious people (those who ranked themselves as "very religious" [9 percent] and "somewhat religious" [44 percent]) had increased and now made up 53 percent ${ }^{1}$ of the population (Kochergina 2017). At the same time, up to 93 percent of the population are friendly toward religion.

The return of religion to the public space in post-Soviet Russia is quite an interesting phenomenon, which confirms the advent of the postsecular era, about which G. Gutman writes: "If secularization desacralizes the sacred and demonstrates its real profane status, then the advent of the post-secular era must be associated with at least partial restoration of the sacred, the discovery of its reality" (Khabermas and Ratzinger 2006, 17). Apparently this trend determines the reemergence and active development of religious institutions in the modern Russian social space, and, subsequently, the reflection of this process in the educational system. This happens at various levels - in private, family upbringing; at the general educational and university levels; and in the actual intra-religious institutions of the church, mosque, datsan, or synagogue.

As Jurgen Habermas writes:

The neutrality of the state authority on questions of world views guarantees the same ethical freedom to every citizen. This is incompatible with the political universalization of a secularist world view. When secularized citizens act in their role as citizens of the state, they must not deny in principle that religious images of the world have the potential to express truth. Nor must they refuse their believing fellow citizens the right to make contributions in a religious language to public debates. Indeed, a liberal political culture can expect that the secularized citizens play their part in the endeavors to translate relevant contributions from the religious language to the public as a whole. (Habermas and Ratzinger 2006, 51-52)

Thus, the formation of a new social reality is taking place, where the past, with its almost total atheism, meets with the present, where religion again seeks to take its place, and shapes a future that is not yet clear. The field research carried out by the author of this article can pro-

1. Citation from the article "Religiosity" at URL https://www.levada.ru/2017/07/18/ religioznost/: "There is an increase of those who counts themselves as predominantly religious people: for the last three years this number increased from $35 \%$ to $53 \%$, mostly at the expense of the indistinct mass of those who consider themselves as "to some extent religious" $-44 \%$. Only a small percentage considers themselves "very religious" (9\%). One third consider themselves as "not too religious" (33\%). For the last three years there has been a sharp decline in the number of atheists and non-believers - from 26 to $13 \%$. 
vide some insights into the trends in the teaching of religion to children in modern Russia, based on materials from the Republic of Tatarstan.

\section{Teaching the Course "The Basics of Religious Cul- tures and Secular Ethics" (BRCSE) in the Republic of Tatarstan}

As mentioned above, modern Russian society is now searching for a national idea. One answer to this question could be the revitalization of religion:

In practice, the development of national concepts has often been combined with religious and ethnic identity. In the context of the worldwide trend of religious revival, the appeal to the church as the guardian of national and cultural identity becomes a necessary component of the process of self-identification of the people. (Orlov 2012)

As a concrete step in realizing this idea, the Basics of Religious Cultures and Secular Ethics (BRCSE) course was introduced from September 1, 2012, in all the schools of the Russian Federation. The course consists of six modules, and students (or their parents) have the right to choose one for study. The thirty-four-hour course is taught in the 4th grade, usually in the first half of the year. According to the results of 2013-2014 academic year, almost half of the students (46\% percent) chose the module "Basics of Secular Ethics," 20 percent chose the "Basics of Orthodox Culture" (BOC), 19 percent chose "The Basics of World Religious Cultures," 4 percent chose "The Basics of Islamic Culture," and less than 1 percent chose "Fundamentals of Jewish Culture" and "Fundamentals of Buddhist Culture." Against this background, the Republic of Tatarstan looks somewhat different:

Table of choices by year ${ }^{2}$

\begin{tabular}{lccc}
\hline & 2013 & 2014 & 2015 \\
& & & \\
\hline Basics of World Religious Cultures & $61.3 \%$ & $37.8 \%$ & $46.4 \%$ \\
The Basics of Secular Ethics & $38.7 \%$ & $62.2 \%$ & $53.6 \%$ \\
\hline
\end{tabular}

2. The Ministry of Education and Science of the Republic of Tatarstan annually monitors research on implementation of this course in public schools. The results are published on the following site: http://orkce.apkpro.ru/doc/m_seminar_2/brshr_28_o3_15.pdf. 
Parents in Tatarstan preferred their children to study the two modules "Basics of World Religious Cultures" (four religions are studied within the framework of this module-Christianity, Islam, Judaism and Buddhism), and "Basics of Secular Ethics" (this module is devoted to the study of ethical issues - the problem of moral choice between good and evil, historical examples of ethical systems, universal virtues). According to the data from other national republics, parents in Kabardino-Balkaria choose similarly. In Bashkortostan, which neighbors Tatarstan and is similarly divided by ethnic and confessional factors (54 percent of the population in Tatarstan and 55 percent in Bashkortostan are ethnic Muslims ${ }^{3}$ ), the choice of modules is as follows: "Basics of Secular Ethics" - 73.5 percent, "Basics of World Religious Cultures" - 21.7 percent, "Basics of Islamic Culture" - 4.2 percent, and "Basics of Orthodox Culture" - 0.79\% percent.

Table of BRCSE module choices by region with a Muslim majority

\begin{tabular}{|c|c|c|c|c|c|c|}
\hline $\begin{array}{l}\text { National } \\
\text { Republic /\% of } \\
\text { Muslims }\end{array}$ & $\begin{array}{l}\text { Basics of } \\
\text { Secular } \\
\text { Ethics }\end{array}$ & $\begin{array}{l}\text { Basics } \\
\text { of World } \\
\text { Rel Cult }\end{array}$ & $\begin{array}{l}\text { Basics of } \\
\text { Orthodox } \\
\text { Culture }\end{array}$ & $\begin{array}{l}\text { Basics of } \\
\text { Islamic } \\
\text { Culture }\end{array}$ & $\begin{array}{l}\text { Basics of } \\
\text { Buddhist } \\
\text { Culture }\end{array}$ & $\begin{array}{l}\text { Basics } \\
\text { of } \\
\text { Judaic } \\
\text { Culture }\end{array}$ \\
\hline $\begin{array}{l}\text { Bashkortostan / } \\
55^{4}\end{array}$ & 73.5 & 23.7 & 0.79 & 4.2 & o & o \\
\hline Dagestan / 95 & 21.4 & 39 & $\begin{array}{l}0.008 \text { (or } \\
3 \text { kids) }\end{array}$ & 39.5 & o & o \\
\hline Ingushetia / 98.7 & o & o & o & 100 & o & o \\
\hline $\begin{array}{l}\text { Kabardino- } \\
\text { Balkaria / } 67\end{array}$ & 38.6 & 61.4 & o & o & o & o \\
\hline $\begin{array}{l}\text { Karachaevo- } \\
\text { Cherkessia /66 }\end{array}$ & 28 & 38.3 & $4 \cdot 3$ & 29.4 & o & o \\
\hline Tatarstan / 54 & 62.2 & 37.8 & o & o & o & o \\
\hline Chechnya / 99 & $\mathrm{o}$ & o & 0.36 & 99.64 & $\mathrm{O}$ & 0 \\
\hline
\end{tabular}

Comparison of the preferences in choices of BRCSE modules in Muslim regions of the Russian Federation indicates that in polyconfessional regions the choice of confessional modules is not high. This

3. The term "Ethnic Muslims" refers to Tatars, Bashkorts, Azeris, Uzbeks, or any other ethnic group who have historically (no less that 2-3 centuries back) belonged to the Islamic Civilization.

4. The number after the slash represents the percentage of Muslims, which is counted according to the data of Russian Federation census carried out in 2010. 
is due to the fact that most parents tend to compromise when choosing modules, which leads to an increase in the percentage of the secular modules, that is, of "Basics of Secular Ethics" and "Basics of World Religious Cultures."

Several things also should be said about the attitude of representatives of the religious establishment to the issue of teaching BRCSE as it is reflected in Tatarstan's media. The debate in the public space was initiated by the Orthodox clergy, including Patriarch Kirill and Feofan, metropolitan of Tatarstan, who was recently appointed in place of of Metropolitan Anastasii. They have repeatedly protested the failure to teach the religious module "Basics of Orthodox Culture" in the Republic of Tatarstan. Thus, Patriarch Kirill, in an interview on the official website of the Moscow Patriarchate, comments:

There are only a few regions where problems with the choice of the BRCSE still persist. There are literally a few such regions where the choice of the Basics of Orthodox Culture clearly does not correspond with the structure of the population. There is also a "unique" region, Tatarstan, where the regional authorities consider it possible for people to decide what they should study within the framework of BRCSE, and what not. The Basics of Orthodox Culture is not allowed. ("Religioznoe obrazovanie" 2015)

Before his move from Ulyanovsk to Kazan, Metropolitan Feofan also said: "As for my new see [in Kazan], there are two main religions. Knowledge by Muslims of their religion is an opportunity to preserve society from the challenges that we have now." The same is true of the Orthodox. "I believe that, in my new diocese the 'Basics of Orthodox Culture' should be taught. Just like the 'Basics of Islam.' And other traditional religions. " (Feofan 2015)

But the Islamic religious establishment has a different view on the issue. Rafik Mukhametshin, the deputy mufti responsible for education, and at the same time, rector of the Russian Islamic Institute, says:

There were no complaints from Muslims that they were not allowed to study the module "Basics of Islamic Culture" delivered to the Muslim Religious Board of the Republic of Tatarstan. We, being religious organizations, are interested in an additional platform, but the teachers fear that the classes will be divided along denominational lines." ("Tatarstanu ukazali" 2015) 
Thus, among the representatives of the two main religions in Tartarstan - Orthodoxy and Islam - there is a difference in the vision of the situation with the teaching of confessional modules within the framework of the BRCSE course. Russian Orthodox Church authorities are more inclined to introduce courses on religion into the public school system in the Republic of Tatarstan, whereas Muslim leaders, being a minority in the Russian Federation, are more cautious in this respect.

Gulzada Rafailevna Akhmerova, the deputy head of the General Education and Final Certification Department (Ministry of Education and Science of the Republic of Tatarstan), who is responsible for the teaching of BRCSE, noted that Tartarstan's schools offer the choices they do because

There are so many mixed marriages, ${ }^{5}$ so everything is intertwined here, that when they gather a parent meeting, parents themselves come to such a decision consciously. No one forces anyone to choose, parents make their own decision about choosing a module. ${ }^{6}$

The choice of religion in cases of mixed marriages is often quite difficult. Researchers note that the mother often determines the religion and nationality of a child. At the same time, given that Russian culture is dominant in the Russian Federation, religion and ethnicity tend toward Russian identity. It should be noted as well that there are sometimes cases where ethnic Russians adopt Islam as a result of interethnic marriages, both in those cases when the husband is a Tatar and a practicing Muslim, and those when the wife is a Tatar. The bitter experience of the 1990 s in the Republic of Tatarstan, when ethnic conflicts were widely discussed (Ageeva 2015), showed that only a balanced and thoughtful policy in the sphere of interethnic and interfaith relations can lead to peace and harmony in society. From this point of view, caution in choosing secular modules for children seems quite justified.

However, what should parents do who want their children to study one or another religion when it is impossible in public schools? In these cases, there is confessional religious education, which in three decades has come a long way from its almost complete absence to a

5. According to statistics, 6,650 marriages (or 21 percent) were mixed in 2010. http://zags. tatarstan.ru/rus/file/pub/pub_67556.pdf.

6. Authors interview with G. R. Ahmerova on July 24, 2017. 
fully-fledged institution of teaching religion for Tatarstan's two main confessions - Islam and Orthodoxy.

It should be noted that this research is focused only on studying Islamic education and teaching Islamic culture to children in Tatarstan due to the general thrust of the author's research. The study of the teaching of Orthodoxy, as well as of other religions, remains beyond the scope of consideration here.

\section{The Revival of Islam and Religious Education in the Republic of Tatarstan in the Late 2oth to Early 21st Centuries}

The history of Islam for Tatars has lasted for more than a millennium (since 922) and has become a part of the self-awareness of the people, in which ethnicity and religion have blended into one indissoluble whole. Seventy years of atheistic propaganda did not destroy religious identity, despite the fact that one of the main tasks of the Soviet government was "the replacement of religious identity by secular ethnic cultures, which were supposed to harmoniously interact within the concept of "friendship of the peoples"' (Luehrmann 2011, 4). Even in the late Soviet years, during the 60s and 70s, certain religious rituals were performed: the naming ceremony (isem kushu), male circumcision (sunnat), weddings (nikah), and funerals (jenaza). Rituals associated with funerals, even in urban areas, were practiced by 67 to 73 percent of Tatars. Part of the funeral ceremony was the rites of remembrance of the deceased, which were usually held on days three, seven, and forty, as well as on every anniversary of the death of the deceased. This ritual is called Koran Ashy or Olylar Ashy in the Tatar language; it included abundant treats for relatives and the invitation of a mullah or abystay, ${ }^{7}$ who read the Qur'an and said special prayers dedicated to the dead (Bagyshlau). During these rites - at which children and numerous relatives were present (a feast was arranged for them after the departure of elderly guests) - the Qur'an was read in Arabic, words from the prerevolutionary religious vocabulary of the Tatar language (which the Soviet authorities tried to erase from the memory of the people) were delivered and then preserved in the mentality of the Tatars. Mostly due to that ritual they perceived Islam as a part of their culture and life. Therefore, when in the early 90 s the bans were lifted, people again turned to religion, and they accepted it

7. Abystay - usually an older woman, who can read the Qur'an in Arabic. 
not only as a form of pure spirituality, but also as a form of national culture and identity.

At the end of the Soviet era in 1986, only eighteen Muslim communities were registered in Tatarstan. However, at the beginning of the 9os, the government gradually started to return Kazan's historic mosques to believers. At the same time, the construction of new mosques began. By 1999, there were already 937 mosques in Tatarstan. With the increase in the number of new mosques, the Muslim Religious Board in Ufa (DUMEC - Dukhovnoe upravlenie musul'man Evropeiskoi chasti Rossii i Sibiri) started to have difficulties with the volume of work and could not provide adequate services on numerous issues for the fast-growing Muslim community. Some regions established their own local religious boards, which were independent and not subordinate to the Muslim Religious Board in Ufa. In Kazan, the Muslim Religious Board of the Republic of Tatarstan (MRB of RT) was registered in 1992; at that time it was headed by Gabdulla Galiullin. Among the MRB of RT's priorities were opening new mosques, charity, the organization of the Hajj to Mecca, and the development of Muslim education.

Before the 1990s, Islamic education in the Republic of Tatarstan was available only through teachers who conducted education at home. Among the famous teachers of the time, Abdulhabir hazrat Yarullin, Ahmadzaki hazrat Safiullin, Garifulla ishan Zainullin, Rashida Abystay Iskhakova, and a number of other religious figures who maintained their adherence from prerevolutionary times should be mentioned. In the early 90s, mosques began to organize free courses for all who wanted to acquire a basic knowledge of Islam. Over the last three decades this form of teaching children and adults has become structured and standardized. To date, according to the rector of the Russian Islamic Institute, Rafik Mukhametshin, up to thirty thousand people in the Republic of Tatarstan have taken advantage of this education.

The second stage of Muslim education is the secondary professional schools or madrassas. In Tatarstan, the first madrassa was founded in the city of Chistopol by Gabdulkhak Samatov, then the imamhatib of the Chistopol Mosque. It was in this mosque at the end of 1990 that a group of twenty students (shakirds) was recruited. A year later, the madrassa, along with its founder, moved to Kazan and became known as a madrassa at the Zakabany Mosque. In 1993, it was officially registered as the Kazan Higher Muslim Madrassa (KHMM), named after the thousandth anniversary of the adoption of Islam (by Bulgars). 


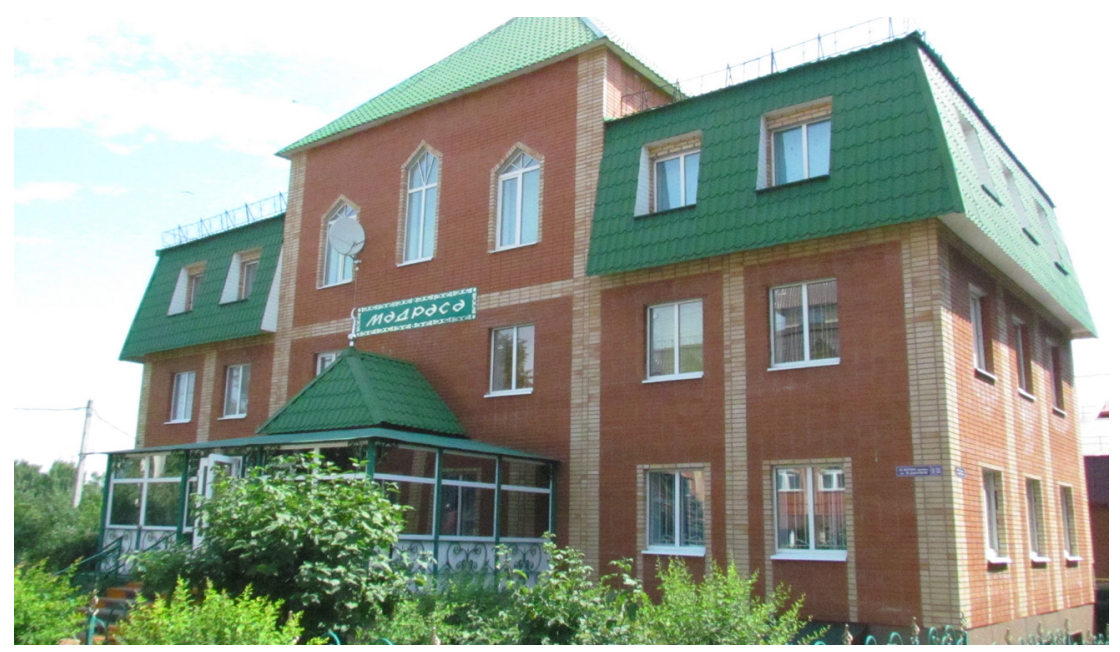

The Gabdulla ibn Masgud Madrassa in the city of Mamadysh. Author's photo, 2017.

In the 1990s, about twenty madrassas were opened, but not all of them have stood the test of time. Thus, three madrassas in Naberezhnye Chelny - Nuretdin, Ayub and Yoldyz - as well as the Ishmuhammat madrassa in Elabuga were closed. Although legally registered as higher educational institutions, the Ramazan madrassa and Kazan Islamic University's Muhammadiya madrassa never began working. There are nine madrassas operating in Tatarstan at the moment (2017).

Higher professional religious education in the Republic of Tatarstan can be obtained at the Russian Islamic Institute (it issues a state diploma in such areas of preparation as theology, linguistics, journalism, and economics) and the Kazan Islamic University (which issues a non-state diploma in the specialization "bachelor of Islamic knowledge"). In September 2017, the Bulgarian Islamic Academy was opened, which trains masters and doctors in the field of Islamic Knowledge.

\section{Teaching Islam to Children}

The very first approach to religion usually happens within the family, where parents introduce the child to a certain tradition - ethical or religious or a mixture of both. The next step in preschool Islamic education is usually the Muslim kindergarten. Even quite recently, the lack of such institutions made finding a place for one's child difficult. Now there are quite a lot of Muslim kindergartens. Their distinctive 
features are halal food and the presence of Muslim-educated teachers, usually women who wear the hijab and teach some elements of Islamic culture. Below is the description of subjects taught taken from an advertisement on the Internet:

The program will include: learn the Arabic alphabet with correct pronunciation, memorizing small Suras of the Kuran, lessons about monotheism, in the place of fairy tales true stories of the prophets, in between small classes will be educational games, making simple toys with their own hands, and so on. ("Kindergarten Day" 2018)

Here is another description of what is taught in a Muslim kindergarten:

By law, we do not have the right to teach children Akyde and Fiqh, but we try to tell the children, in a language they understand, that everything is created by the Almighty.

When we read prayers with children, we make two raka'ats, without detailed elaboration, i.e., there is a certain standard, and we try to keep to the middle, because parents bring up children on different Madhabs.

We tell stories about the prophets in the form of tales, then we perform a creative task with the main characters. For example, according to the life story of the Prophet Salih (peace be upon him), we know that in his history a camel and mountain participate, and accordingly we make their creative models. ("Muslim Kindergarten" 2016)

Attending such a kindergarten usually costs from 5,000 to $15,000 \mathrm{ru}-$ bles per month.

The next and most important step in the religious education of children is represented by the system of elementary schools established near mosques. This system started to form in the early $90 \mathrm{os}$. The course participants were both children of five to six years old, and citizens who are far beyond sixty. Often the groups were not divided by age or gender. They were taught the basics of Islam and the recitation of the Quran (Tajwid). Some of the most capable students were taught Qur'anic recitation individually. Classes usually took place once or twice a week. Very often teachers did not have professional training; mostly they had been educated by individual private teachers during the late Soviet period or took short courses near mosques themselves.

The lessons were held either on weekends or in the evenings on working days. The purpose of these courses was the moral upbringing 
of the younger generation, as well as the elementary religious education of adults. The term of study ranged from one year to three or four years. At the same time, control over attendance was not strict: some quit school after a while, some left and then reappeared on the courses, some joined the classes in the middle of the year.

The leading place among the abovementioned educational institutions in the early 2000s was occupied by the Faruk Madrassa, opened near the Bulgar Mosque, located in a densely populated area of Kazan. Its task was not the training of professional clergymen, which is usually associated with the concept of the madrassa, but the education of religiously uneducated Muslims. Each of the teachers (mugallim) formed his own group. Several teachers taught at different times, so groups of ten to forty people studied almost every day of the week. The term of study was four years. As a rule, textbooks were not used. A thin booklet called "Fan Tajwid" was used in lessons on the recitation of the Qur'an, as well as the Qur'an itself, and the fundamentals of the dogma were acquired mainly on the basis of lectures and sermons.

In these same years, various foreign religious organizations and foundations sponsored the establishment and operation of many madrassas. Among them, in particular, were the Saudi Foundation Ibrahim Bin Abdulaziz Al Ibrahim, which published numerous translated works on Shariah. Other organizations were represented by Dar Ul-Hadith, Dar UlJhil, Dar Ul-Fikr, and Dar Ul-Mugrif (Egypt, Syria, Jordan, Lebanon respectively). These organizations provided assistance under the condition that the curricula, the list of educational literature, and the teaching staff were under their control. By the late 1990s, the work of many international funds in the territory of the Russian Federation was banned due to the increased incidence of illegal activities involving graduates and students of some madrassas, as well as the situation in Chechnya.

Gradually, diverse segments of society, including many Muslims, representatives of the academic community, and state authorities, came to the understanding that in order to counterbalance foreign influence, it was necessary to form a system of Muslim education that would be based on educational practices that were traditional for Russian Islamic societies (which were very diverse in different regions of Russia). So, in 2014, a new program for religious education was approved in Tatarstan that includes a three-year course on such subjects as Islamic ethics (Ahlyak), the doctrine of Islam (Aqida), recitation of the Qur'an (Tajwid - only for the first year), Islamic law (Fiqh), the Qur'an, the biography of the Prophet Muhammad (Sirah), and the Arabic language (two years - the second and third year). 
An analysis of the literature recommended for these courses (a total of sixy-five publications) shows that at this initial level of teaching knowledge of Islam, aimed mostly at children and people of the older generation, there are five main types of educational literature:

1. Textbooks written by modern Tatarstanian authors (Ramil Adygamov, Gabdelhak Samatov, Valiulla Yakupov, Rishat Kalimullin, etc.), 37 books or 57 percent.

2. Textbooks by authors who taught in Jadid madrassas (Rizaetdin Fakhretdin, Ahmad-Hadi Maksudi, Salihjan Barudi, etc.), 9 titles or 14 percent.

3. Modern secular textbooks, mainly in Arabic, on the history of theological thought (Alexander Kovalev and Grigory Sharbatov, Rafik Mukhametshin, Taufik Ibrahim), 7 editions or 10 percent.

4. Medieval books (Abu Hamid al-Ghazali, Abdurrahman Karabash and others), 6 titles or 9 percent.

5. Foreign textbooks written in the 19th to 21st centuries that are now used in some countries of the Muslim East (Muhammad Ashik, Muhammad Kifayatullah, Mustafa Chagirdzhi/Turkey), 8 percent or 5 titles.

The program, constructed so that it uses primarily the works of local authors as teaching aids, is called upon to form Islamic views in a form adapted to modern Tatarstan realities. Here I would also like to note that the overwhelming majority of mosque courses are using Tatar as the language of instruction. According to Muslim officials, this could help to protect the Islamic community from globalist versions of Islam such as those described in Globalized Islam by Olivier Roy, whose adherents seek not to preserve national languages and cultures, but instead use the most widespread languages to retransmit its cultural codes. In the context of the Russian Federation that means, first of all, the use of the Russian language as a language of religion and recruitment.

In the last decade the Shamil Madrassa, which operates near the Kazan Nury Mosque, has become the most famous religious school in Kazan. The teaching staff of this institution are the leaders in Islamic education for children. Teachers of this madrassa developed special techniques for teaching children starting from one and a half years. Using the textbook Qaida al-Nooraniya, written by the Indian scientist Nur Muhammal Haqqani (1856-1925) for teaching the Qur'an, the teachers teach children by the age of six to independently read (not recite) the Qur'an in Arabic. Groups are divided by age from 1.5 years (classes are held for toddlers together with parents) to older adolescence. 
Another example of children's Islamic education is the unique Muslim private school of Usmaniya, which offers eleven years of education. The Muslim Religious Board of the Republic of Tatarstan founded this institution. The program includes Arabic language and in the afternoon, children study in the nearby mosque of Nur al-Islam, where courses on the history of Islam, the history of the prophets, and reading and memorizing the Qur'an are taught. There are about a hundred children studying there.

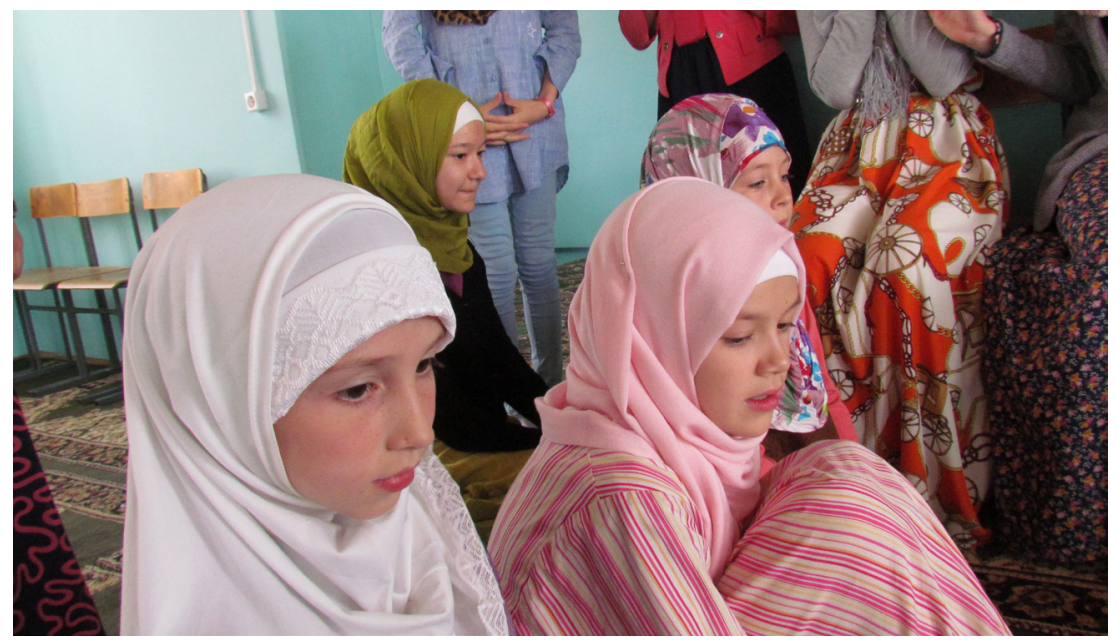

Summer camp at the madrassa in the city of Kukmor (a group of girls). Author's photo, 2017.

Another way to familiarize children with Islamic culture and religious knowledge is the summer camps or Muslim centers for children's daytime care at mosques. They do not call them summer camps because of the strict requirements for summer camps where children live, study, and sleep. Muslim organizations have moved to Muslim daytime care for children in the form of a day program, although Muslim children's camps are also conducted by those capable of working through the obstacles of normative acts, requirements, and regulations.

Leysan Firdusovna Ganieva, mother of four, is one such advocate of Muslim camps. She is also the organizer of the creative group Bakhet Akkychy (Key of Happiness), which is famous for working with Muslim children. In an interview on the question of why she does so much in the field of Muslim camps, she replied: "I do this in order to live in a society where people and our children are safe, and this is such a society where morality should be in a highest level. Religion is able to provide the most moral up- 
bringing." In 2015, Kazan Federal University began special programs on the issue of Muslim camp organization. Among these are programs on the "Regulatory and Legal Documentation for Organization and Conduct of Summer Camps for Muslim Children," "Sanitary and Epidemiological Requirements for the Organization and Maintenance of Children's Summer Camps," and "Modern Approaches to the Implementation of Program and Methodological Support for Summer Muslim Children's Camps." Within the framework of the thematic block on "Preparation of Counselors," the following topics were considered: the organization of the leader's work, the pedagogical style of the leader, the pedagogical ethics in the conditions of the children's summer camp, the method of collective education, the features of creating a temporary children's collective, self-management and co-management in the camp, the healing process in the summer camp, the provision of first aid, pedagogical approaches to working with children of different ages, methods of organization of children's group activities, and the development and presentation of creative projects, including scenarios, teaching materials, games, cards, decorations, and so on.

If the camp is organized according to all rules established by the state, then children stay for a whole session (from five days to three weeks) with accommodation and meals. All the camps that were visited during field research in 2017 (in cities and the district central villages of Kukmor, Baltasi, Mamadysh, Pestretzi, and Almetyevsk) were day camps. They began only July 1, due to the end of fasting in the month of Ramadan (June 26). Religious instructions in Kukmor, for example, included three lessons of thirty minutes before lunch (the list of subjects changes from day to day) on such courses as reading the Qur'an, Muslim ethics (Ahlak), Arabic language, the history of Islam, and the life of the Prophet Muhammad. After lunch in some camps children listened to short (fifteen-minute) sermons, then had play time with games, and at three o'clock in the afternoon children usually returned home. Sometimes children had bus tours around the city and visited memorable places.

Another current form of children's Islamic education in Tatarstan is the educational work of imams (Muslim preachers) at public schools. Field research, especially in relatively mono-confessional villages and small towns of Tatarstan where the majority of the population are Tatar, revealed that imams often have certain opportunities to preach Islam to children. Imams are invited to schools at the beginning of the year (September 1) and at the end (the so-called Last Bell, held at the end of May). There they give speeches, make gifts to first-graders and graduates. Sometimes the Muslim community headed by the imam arranges a special celebration at schools during the Feast of Sacrifice (Kurban 
Bayram) or Ramadan (Gaid/'Id), with abundant meals as well as different contests for children in various aspects of Islamic culture including reciting the Qur'an or knowledge of the basics of Islam.

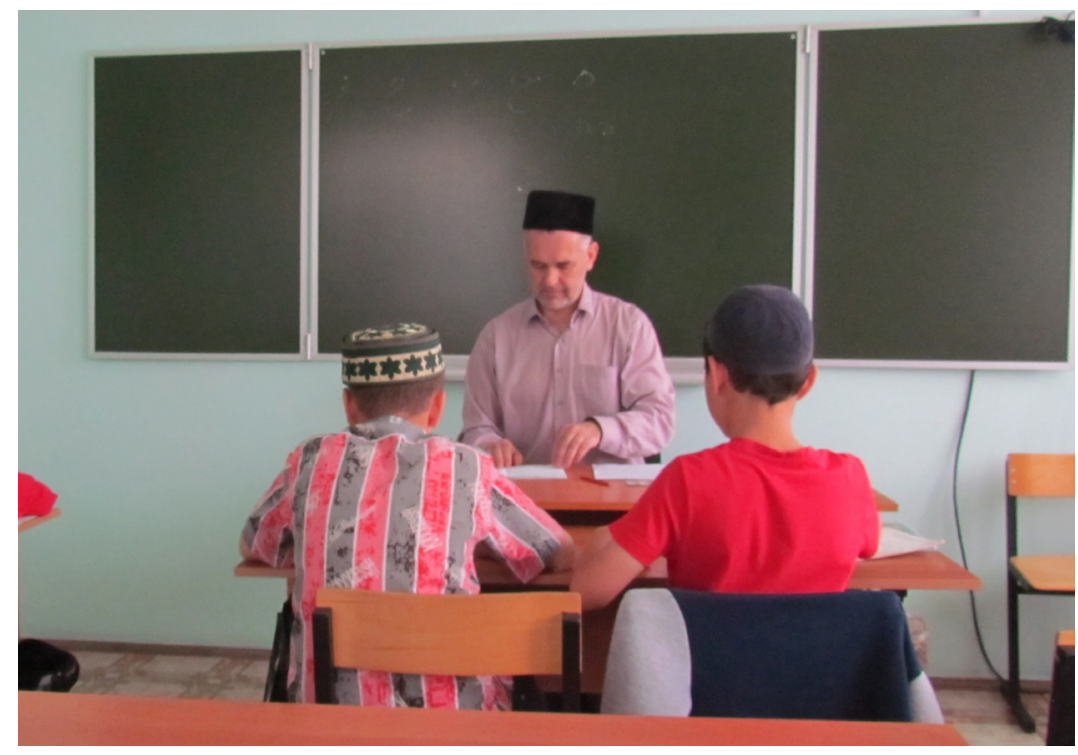

Arab language lesson during summer camp at the madrassa in the city of Kukmor. Author's photo, 2017.

Field research also provided information about another form of educational work carried out in public schools by the imam, that is, more or less regular conversations between Islamic preachers and school children. Sometimes such conversations are associated with a tragic event. For example, in one of the villages a schoolboy committed suicide, and the imam was invited to the schools to explain the attitude of religion toward this tragic phenomenon. Or, in another village there is a rehabilitation center for drug addicts, and one of its patients fled and died right in the village. On this occasion, the school administration also decided to arrange a meeting of students with the imam. Imams are also invited to talk without any special reason, and simply for moral instruction.

There is an interesting story told by the imam of the central mosque in Baltasi, who regularly receives invitations to talk to senior class students about relationships between young people in order to prepare them for future family relationships. One day he brought a package of chocolates to a conversation with young ladies in the eleventh grade. He poured them out onto the table and invited them to take one. After each took her treat, 
the imam drew the girls' attention to the fact that one candy that did not have a wrapper was left untouched on the table - no one wanted to take it. This is the way the imam tried to convey the idea of chastity to those girls.

There are also frequent cases where the imam is invited for regular weekly conversations with primary school students on matters of morality. So, the imam of Elhovo village of Almetyevsky district, at the request of parents and the invitation of the school administration, conducts regular lessons in ethics for children of the Tatar first grade class every Wednesday for half an hour from 7:30 to 8:00 am.

And finally there are various competitions for children, such as the Qur'an recitation contest, held every year at the madrassa in Kukmor. The same competition is held in Baltasi and many other districts of the republic. For example, a contest called "Brothers and Sisters of Syuyumbika," is held by the Kazan Yardam Mosque. At the Buinskoye Madrassa, a competition for knowledge of Islamic culture is held.

\section{Conclusion}

The above analysis of the specifics of subjects related to the teaching of religion in general and Islam in particular for children in the Republic of Tatarstan testifies to a rather interesting situation. In the Russian Federation, with its concept of Russian society as a single community, there are ethnic cultures and confessional communities that have their own ideas about man, and it is very difficult to combine them in such a way that they do not come into conflict with one another. This is not to mention the fact that within the framework of one community, for example, a confessional community, the concept of a perfect person could be different depending on the region: for example, the Muslims of the Northeast Caucasus - Chechnya, Ingushetia and Dagestan - have a completely different view of the system of religious education than Muslims of the Volga-Ural region - Tatarstan and Bashkortostan. Even more than that, within the framework of one national republic, for example Tatarstan, there are different concepts of Islam - there are teachers who tend more toward fundamentalistic ideology and those who are more moderate.

In modern postsecular society, according to Jürgen Habermas, "a greater degree of communicative rationality expands - within a communication-community - the scope for unconstrained coordination of actions and consensual resolution of conflicts" (Habermas 1987, 17). Thus, understanding the processes currently taking place in the field of religious education for children by various players on the educational stage can help us to understand the boundaries encountered in the 
context of achieving both the general and the private goals of various groups. Every social community has its own idea of the role of religion in the upbringing of children, and the real state of things in this area is determined by the economic and political capabilities of certain groups in modern Tatarstan. At present, the situation with the teaching of religion is in a delicate state of balance. It will be difficult to maintain this state for long. The number and economic strength of Muslim communities grow, while the secular community and representatives of other religious cultures are discontented with the growth of Islam. The issues of religious extremism and terrorism, which dictate certain methods of control over the religious sphere in the republic by the state, also remain relevant. In any case, the consideration of regional, ethnic, and confessional specifics, as well as the idea of social peace and well-being, remain the most reliable way of building and reforming the system of modern education in its gradual shift from the past to the future.

\section{References}

Ageeva, Liubov'. 2015. "1991 god: Istoriia odnoi publikatsii [On the history of one publication]. May 18. http://history-kazan.ru/kazan-vchera-segodnya-zavtra/retrospektiva/ novejshaya-istoriya-s-avgusta-1990-goda/15867-1991-god-istoriya-odnoj-publikatsii.

“Bol'shinstvo shkol'nikov v RF vybiraiut dlia izucheniia svetskuiu etiku v ramkakh kursa ORKSE" [A majority of school children in the RF choose to study secular ethics within the framework of the ORKSE course]. 2014. Interfaks-Religiia. September 19. http://www.interfax-religion.ru/?act=news\&div $=56506$.

Diurkgeim, E. 1996. Sotsiologiia obrazovaniia [Sociology of education]. Moscow: Intor.

Feofan, Metropolitan. 2015. “V moei novoi eparkhii ‘Osnovnoi pravoslavnoi kul’tury' dolzhen byt" [There should be "Basics of Orthodox Culture" in my new diocese]. Biznes Online. July 15. https://www.business-gazeta.ru/article/136692.

Habermas, Jürgen. 1987. The Theory of Communicative Action: Reason and the Rationalization of Society. Vol. 1. Boston: Beacon Press.

Habermas, Jürgen, and Joseph Ratzinger. 2006. The Dialectics of Secularization: On Reason and Religion. San Francisco: Ignatius Press.

Iag"kub, V. 2003. Moselman magarife [Muslim education]. Kazan.

-- - 2006. Islam asylina kaity [Returning to the faiths' essence]. Kazan.

Ian'kova, T. 2017. "Zhil'tsy kazanskoi mnogoetazhnoi protiv stroitel'stva mecheti pod ikh oknami” [Residents of a Kazan multistory building are against the construction of a mosque under their eyes.] Vercherniaia Kazan'. July 12. http://www.evening-kazan.ru/articles/zhilcy-kazanskoy-mnogoetazhki-protiv-stroitelstva-mecheti-pod-ih-oknami.html.

Kemper, M., and A. Bustanov. 2015. "Islam i Russkii Iazyk: Sotsiolingvisticheskie aspekty stanovleniia obshcherossiiskogo islamskogo diskursa" [Islam and the Russian language: Sociolinguistic aspects of the formation of an all-Russian Islamic discourse]. Kazan Islamic Review 1: 212-23.

“Kindergarten Day ‘ABUZAR.”” 2018. Halal Guide. https://halalguide.me/naberezhnye-chelny/organizatcia/detskiy-sad-dnevnogo-prebyvaniya-abuzar. 
Khabibullina, Z. 2017. “Opyt vvedeniia “Osnovy religioznykh kul'tur i svetskoi etiki’ v usloviiakh polikonfessional'nogo regiona" [Experience of the introduction of "Basics of Religious Culture and Secular Ethics" in the conditions of a polyconfessional region]. Elektronnyi nauchnyi arkhiv UrFU. http://elar.urfu.ru/bitstream/10995/46826/1/klo_2017_072.pdf.

Kochergina, E. 2017. “Religioznost”" [Religiosity]. Levada Center. July 18. https://www.levada.ru/2017/07/18/religioznost.

Luehrmann, S. 2011. Secularism Soviet Style: Teaching Atheism and Religion in a Volga Republic. Bloomington: Indiana University Press.

Machneva, O. 2014. "Khalial'nyi detskii sad dlia kazanskoi Alenushki” [A halal kindergarten for Kazan's Alenushka]. Vecherniaia Kazan'. September 3. http://www.eveningkazan.ru/articles/halyalnyy-detsad-dlya-kazanskoy-alyonushki.html.

Nadyrshin, T. 2016. "Problemy prepodavaniia konfessional'nykh modulei kursa 'Osnovy religioznykh kul'tur i svetskoi etiki’ v Respublike Bashkortostan” [Problems of teaching the confessional modules of the course "Basics of Religious Culture and Secular Ethics" in the Republic of Bashkortostan]. Problemy sovremennoi nauki $i$ obrazovaniia 386: 45-47. https://elibrary.ru/item.asp?id=27537336.

Orlov, B.A. 2012. "Natsional'naia ideia Rossii v istorii mysli” [The Russian national idea in the history of thought]. In Natsional'naia ideia Rossii: Kollektivnaia monografiia, 1: 59-79. 6 vols. Moscow: Nauchnyi ekspert.

Piskarev, V.I., and I.V. Safronova. 2012. Osnovyi dukhovno-nravstvennoi kul'turyi narodov Rossii: Osnovy religioznykh kul'tur narodov Rossii; Kniga dlia uchitelia [Foundations of spiritual-moral culture of the people of Russia: Foundations of the religious cultures of the peoples of Russia; Book for teachers]. Moscow: Russkoe slovo.

"Problemy prepodavaniia ORKSE v Respublike Bashkortostan" [Problems of teaching ORKSE in the Republic of Bashkortostan]. 2015. Ufimskaia eparkhiia. http://www.eparhia-ufa. $\mathrm{ru} /$ news/problemy-prepodavaniya-orkse-v-respublike-bashkortostan-4135.

Prokof'ev, M.A. et al., eds. 1967. Narodnoe obrazovanie SSSR. [Public education in the USSR]. Moscow: Prosveshshenie, Moscow: Prosveshchenie.

“'Religioznoe obrazovanie stalo kachestvenee’: Interv'iu Sviateishego Patriarkha Kirilla zhurnalu 'Pravoslavnoe obrazovanie"" ["Religious education has become higher in quality”: Interview with His Holiness Patriarch Kirill.] 2015. Patriarchia.ru. January 26. http://www.patriarchia.ru/db/text/3966661.html.

Roy, O. 2004. Globalized Islam: The Search for a New Ummah. New York: Columbia University Press.

Sakharov, A.N., and K.A. Kochegarov. 2012. Osnovy dukhovno-nravstvennoi kul'tury narodov Rossii: Uchebnik dlia 4 klassa obshcheobraovatel'nykh uchrezhdenii [Basics of spiritual-moral culture of the peoples of Russia: Textbook for fourth grade general educational institutions]. Moscow: Russkoe slovo.

Sinelina, Iu. 2013. "Religioznost' v sovremennoi Rossii” [Religiosity in contemporary Russia]. Otechestvennyi zapiski 1 (52): 243-55.

“Tatarstanu ukazali na religioznoi kurs: Patriarkh Kirill trebuet izucheniia pravoslavnoi kul'tury v shkolakh respubliki" [Tartarstan was instructed on its religious course: Patriarch Kirill demands the study of Orthodox culture in the schools of the republic]. 2015. Interfaks-religiia. January 28. http://www.interfax-religion. $\mathrm{ru} /$ ?act $=$ print $\&$ div $=18171$.

Urazmanova, R.K. 2009. “'Musul'manskie' obriady v bytu tatar” [“Muslim” observances in Tatar daily life]. Etnograficheskoe obozrenie 1: 13-26.

"Zakon ob obrazovanii RF." [Law on education of the Russian Federation]. 2017, July 31. http://zakon-ob-obrazovanii.ru/3.html. 